\title{
PENGARUH SIKAP WAJIB PAJAK PADA PELAKSANAAN SANKSI DENDA, PELAYANAN FISKUS DAN KESADARAN PERPAJAKAN TERHADAP KEPATUHAN WAJIB PAJAK (STUDI EMPIRIS TERHADAP WAJIB PAJAK RESTORAN ORANG PRIBADI DI KOTA MANADO DAN DI KABUPATEN MINAHASA)
}

\author{
Anjeline Kodoati, Jullie J. Sondakh, Ventje Ilat \\ Anjelinekodoati@gmail.com
}

\begin{abstract}
ABSTRAK
Taxes are the largest revenue source in addition to oil and gas. In the era of Indonesia's tax reform, the tax collection system is set to a self-assessment system, which gives full trust to the taxpayer to calculate, pay, and report all taxes that become his obligations. One of the obstacles that may hinder the effectiveness of tax collection is tax compliance. This is happened in every region in Indonesia, including in the Manado City and Minahasa District, which has a decrease tendency of tax compliance since 2010 until 2014 based on the data from the Dinas Pendapatan Daerah Kota Manado (Local Revenue Office of Manado City) and Dinas Pendapatan Daerah Kabupaten Minahasa (Local Revenue Office of Minahasa District). As tax authorities, these offices tried to uphold the norms of taxation by applying administrative sanctions such as fines for taxpayers who are late paying taxes in accordance with the district's legislation, but it has not been able to increase tax compliance in paying taxes. Therefore, this study is aimed to analyze the influence of the attitude of the taxpayer on the implementation of financial penalties on tax compliance, the service tax authorities on tax compliance, and tax awareness on tax compliance. By using qualitative research methods with multiple linear regression, this study concluded that the attitude of taxpayer on the implementation of financial penalties affect tax compliance, service tax authorities did not affect tax compliance, and awareness of tax affect tax compliance.

Keywords : Tax Compliance, Tax Authorities, Tax Awareness.
\end{abstract}

\section{PENDAHULUAN}

Pajak merupakan sumber penerimaan negara terbesar disamping minyak dan gas bumi. Pajak yang dikelola pemerintah pusat merupakan sumber penerimaan negara di dalam APBN, sedangkan pajak yang dikelola pemerintah daerah merupakan sumber penerimaan daerah di dalam APBD. Menurut Soemitro dalam (Mardiasmo:2013:1) Pajak adalah iuran rakyat kepada kas negara berdasarkan Undang-Undang (yang dapat dipaksakan) dengan tiada mendapat jasa timbal-balik (kontra-prestasi) yang langsung dapat ditunjukkan dan yang digunakan untuk membayar pengeluaran umum.

Salah satu kendala yang dapat menghambat keefektifan pengumpulan pajak adalah kepatuhan wajib pajak (tax compliance). Kepatuhan wajib pajak merupakan sikap atau perilaku seorang wajib pajak untuk memenuhi kewajiban perpajakannya dan menikmati semua hak perpajakannya sesuai dengan ketentuan peraturan perundangan yang berlaku. Agar target pajak tercapai, perlu ditumbuhkan secara terus menerus kesadaran dan kepatuhan masyarakat untuk memenuhi kewajiban perpajakan. Kesadaran perpajakan timbul dari dalam diri wajib pajak sendiri, tanpa memperhatikan adanya sanksi perpajakan. Sedangkan kepatuhan perpajakan timbul karena mengetahui adanya sanksi perpajakan. Meskipun demikian, dalam praktek sulit 
untuk membedakan apakah wajib pajak yang memenuhi kewajiban perpajakannya dimotivasi oleh kesadaran atau kepatuhan perpajakan

Berdasarkan data dapat dilihat bahwa dari tahun 2010 hingga tahun 2014 tingkat kepatuhan wajib pajak orang pribadi restoran di Kota Manado dan di Kabupaten Minahasa terus mengalami penurunan. Variabel-variabel yang diperkirakan mempengaruhi tingkat kepatuhan WP adalah sikap wajib pajak, pelayanan fiskus dan kesadaran perpajakan. Berdasarkan hal tersebut maka dirumuskan pertanyaan penelitian sebagai berikut :

1. Apakah sikap wajib pajak pada pelaksanaan sanksi denda berpengaruh signifikan terhadap kepatuhan wajib pajak?

2. Apakah pelayanan fiskus berpengaruh signifikan terhadap kepatuhan wajib pajak?

3. Apakah kesadaran perpajakan berpengaruh signifikan terhadap kepatuhan wajib pajak?

\section{TINJAUAN PUSTAKA}

\subsection{Theory of Planned Behavior}

1. Behavioral Beliefs, merupakan keyakinan individu akan hasil dari suatu perilaku dan evaluasi atas hasil tersebut.

2. Normative Beliefs, merupakan keyakinan tentang harapan normatif orang lain dan motivasi untuk memenuhi harapan tersebut.

3. Control Beliefs, merupakan keyakinan tentang keberadaan hal-hal yang mendukung atau menghambat perilaku yang akan ditampilkan dan persepsinya tentang seberapa kuat hal-hal yang mendukung dan menghambat perilakunya tersebut (perceived power).

Dikaitkan dengan penelitian ini, Theory of Planned of Behavior relevan untuk menjelaskan perilaku wajib pajak dalam memenuhi kewajiban perpajakannya.

\subsection{Teori Atribusi (Atribution Theory)}

Teori atribusi menyatakan bahwa bila individu-individu mengamati perilaku seseorang, mereka mencoba untuk menentukan apakah itu ditimbulkan secara internal atau eksternal (Robbins, 1996). Perilaku yang disebabkan secara internal adalah perilaku yang diyakini berada di bawah kendali pribadi individu itu sendiri, sedangkan perilaku yang disebabkan secara eksternal adalah perilaku yang dipengaruhi dari luar, artinya individu akan terpaksa berperilaku karena situasi.

Teori atribusi sangat relevan untuk menerangkan kondisi internal maupun ekternal wajib pajak dalam memenuhi kewajibannya membayar pajak. Seseorang taat membayar pajak dilihat dari kondisi internal maupun ekternalnya, begitu pula sebaliknya.

\subsection{Teori Pembelajaran Sosial}

Albert Bandura menjelaskan bahwa individu belajar banyak melalui imitasi, dan imitasi melibatkan serangkaian proses kognitif. Bandura menekankan proses kognitif memiliki hubungan yang sangat erat dengan lingkungan dan tingkah laku (behavior).

teori pembelajaran sosial ini relevan untuk menjelaskan perilaku wajib pajak dalam memenuhi kewajibannya membayar pajak. Seseorang akan taat membayar pajak tepat pada waktunya, jika lewat pengamatan dan pengalaman langsungnya, hasil pungutan pajak itu telah memberikan kontribusi nyata pada pembangunan di wilayahnya. Seseorang juga akan taat membayar pajak apabila telah menaruh perhatian terhadap pelayanan pajak, baik fiskus maupun sistem pelayanan pajaknya. Terkait dengan proses penguatan, proses tersebut cukup relevan apabila dihubungkan dengan pengaruh sanksi pajak terhadap kepatuhan wajib pajak. 


\section{HIPOTESIS}

Penelitian ini berusaha menjelaskan mengenai pengaruh sikap wajib pajak pada pelaksanaan sanksi denda, pelayanan fiskus dan kesadaran perpajakan karena diduga akan berpengaruh terhadap kepatuhan wajib pajak. Kerangka pemikiran teoretis penelitian ini disajikan pada gambar

\section{Gambar 1. Kerangka Pemikiran Teoritis}

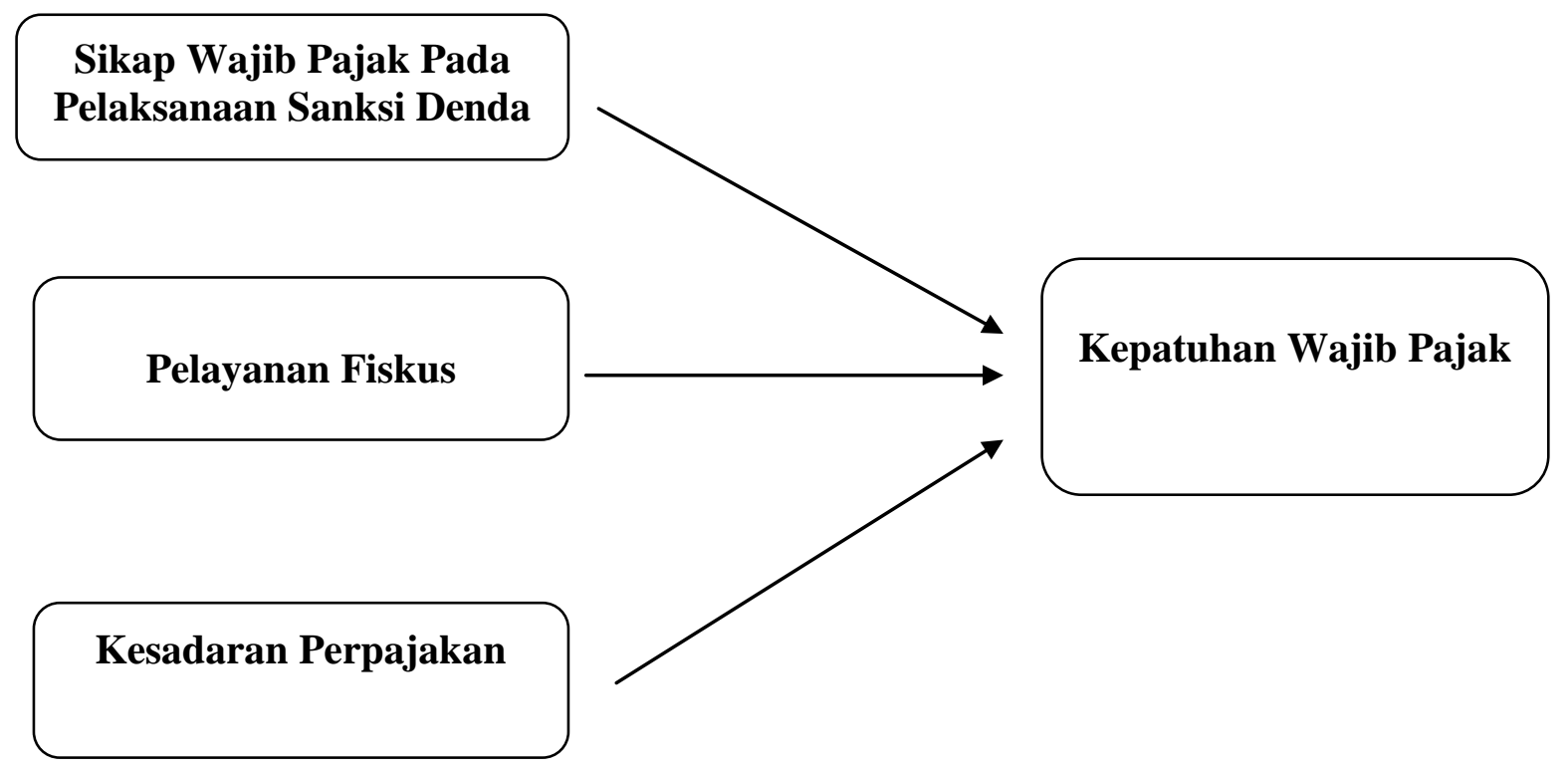

Berdasarkan tinjauan terhadap teori yang ada dan hasil penelitian sebelumnya, maka hipotesis penelitian ini adalah:

$\mathrm{H}_{1} \quad$ : Sikap wajib pajak pada pelaksanaan sanksi denda berpengaruh signifikan terhadap kepatuhan wajib pajak.

$\mathrm{H}_{2}$ : Pelayanan fiskus berpengaruh signifikan terhadap kepatuhan wajib pajak.

$\mathrm{H}_{3}$ : Kesadaran perpajakan berpengaruh signifikan terhadap kepatuhan wajib pajak.

\section{METODE PENELITIAN}

\subsection{Data}

Penelitian ini menggunakan metode penelitian kuantitatif dengan menggunakan dua jenis data, yaitu data primer dan data sekunder. Sumber data primer pada penelitian ini diperoleh langsung dari para WP yang ada di kota Manado dan WP yang ada di kabupten Minahasa. Data ini berupa kuesioner yang telah diisi oleh para WP yang menjadi responden terpilih dalam penelitian ini.

Sumber data ini diperoleh dari Dinas Pendapatan Kota Manado dan Dinas Pendapatan Kabupaten Minahasa selaku Satuan Kerja Perangkat Daerah (SKPD) pemungut Pajak Daerah. Data sekunder dalam penelitian ini berupa jumlah WP efektif, terdaftar dan WP yang menyampaikan SPTPD (Surat Pemberitahuan Pajak Daerah) yang diperoleh dari Kantor Dinas Pendapatan Kota Manado dan Kantor Dinas Pendapatan Kabupaten Minahasa.

Populasi dalam penelitian ini adalah para wajib pajak Restoran yang ada di kota Manado dan Kabupaten Minahasa. Berdasarkan data dari Dinas Pendapatan yang ada di Kota Manado, hingga akhir tahun 2014 tercatat sebanyak 381 WP yang merupakan WP efektif dan data dari 
Dinas Pendapatan yang ada di Kabupaten Minahasa, hingga akhir tahun 2014 tercatat sebanyak 74 WP yang merupakan WP efektif. Sampel yang diambil dalam melakukan penelitian berjumlah 80 responden. Penentuan jumlah sampel responden didasarkan pada pernyataan Heir dkk (2006) yang menyatakan bahwa ukuran sampel yang baik dapat ditentukan dengan cara, jumlah pertanyaan dalam kuesioner dikali lima (5) sampai sepuluh (10). Jadi dalam penentuan jumlah sampel pada penelitian ini, perhitungannya adalah 16 pertanyaan x $5=80$, maka sampel penelitian yang digunakan adalah sebanyak 80 sampel.

\subsection{Metode Analisis}

Model analisis yang digunakan dalam penelitian ini yaitu analisis regrasi linear berganda.

Berikut ini estimasi regresi linier berganda



Lokasi penelitian ini adalah di Wilayah kerja Dinas Pendapatan Kota Manado dan Dinas Pendapatan Kabupaten Minahasa. Waktu penelitian diperkirakan kurang lebih 3 bulan.

\section{HASIL ANALISIS DAN PEMBAHASAN}

\subsection{Hasil Analisis}

Karakteristik responden dikelompokkan menurut usia, jenis kelamin, dan lama melakukan usaha. Untuk memperjelas karakteristik responden yang dimaksud, maka disajikan tabel mengenai responden.

\section{Tabel 1. Karakteristik Responden}

\begin{tabular}{llll}
\hline \multicolumn{1}{c}{ Data Deskriptif } & \multicolumn{1}{c}{ Keterangan } & Jumlah & Prosentase \\
\hline Jenis Kelamin & Laki-laki & 55 & $69 \%$ \\
Usia & Perempuan & 25 & $31 \%$ \\
& Antara 21 th -30 th & 7 & $9 \%$ \\
& Antara 31 th -40 th & 33 & $41 \%$ \\
Lama & Antara 41 th -50 th & 23 & $29 \%$ \\
Usaha & Diatas 50 th & 17 & $21 \%$ \\
& Kurang dari 5 th & 26 & $33 \%$ \\
& Antara 6 th -10 th & 25 & $31 \%$ \\
& Antara 11 th -15 th & 16 & $20 \%$ \\
& Diatas 16 th & 13 & $16 \%$ \\
\hline
\end{tabular}

Sumber data diolah (2016)

\section{Koefisien Determinasi}

Nilai koefisien determinasi yakni $\mathrm{R}$ Square variabel $\mathrm{X}_{1}$ (Sikap WP), $\mathrm{X}_{2}$ (Fiskus), $\mathrm{X}_{3}$ (Sadar) adalah sebesar 0,332 atau 33,2\%. Hal ini menunjukan bahwa besarnya pengaruh variabel bebas, yaitu Sikap Wajib Pajak, Pelayanan Fiskus dan Kesadaran Perpajakan terhadap variabel terikat yaitu Kepatuhan Wajib Pajak yang diterangkan oleh model persamaan dalam penelitian 
ini adalah sebesar 33,2\%, sedangkan sisanya diterangkan oleh faktor-faktor lain yang tidak dimasukan dalam model regresi.

\section{Analisis Regresi Linear Berganda}

Tabel 2. Analisis Regresi Linear Berganda

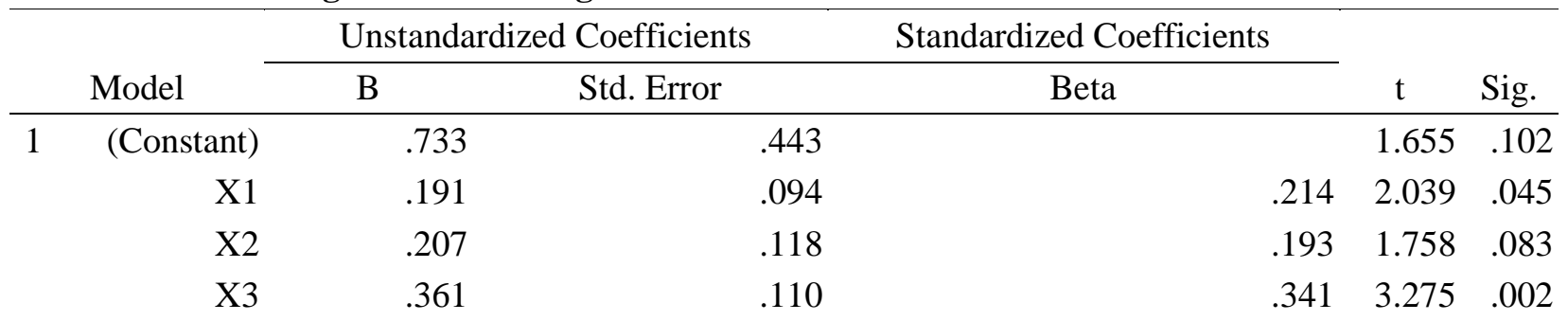

a. Dependent Variable: Y

Model persamaan regresi linear berganda yang digunakan adalah sebagai berikut :

Uji F

$$
\mathrm{Y}=\mathbf{0 . 7 3 3 + 0 . 1 9 1 + 0 . 2 0 7}+\mathbf{0 . 3 6 1}+
$$

Hasil uji $\mathrm{F}$ dengan menggunakan tingkat signifikansi sebesar 0.000 lebih kecil dari tingkat signifikansi statistik sebesar 0.05. Hal ini menunjukan bahwa secara bersama-sama variabel Sikap WP $\left(\mathrm{X}_{1}\right)$, Fiskus $\left(\mathrm{X}_{2}\right)$, dan Kesadaran $\left(\mathrm{X}_{3}\right)$ berpengaruh terhadap kepatuhan Wajib Pajak

Uji Statistik t (Uji t)

Hasil pengujian ini sebagaimana terdapat pada gambar 5.9 akan menjawab hipotesis 1 sampai hipotesis 3 dari penelitian ini antara lain : Pengaruh sikap wajib pajak pada sanksi denda terhadap kepatuhan wajib pajak, pengaruh pelayanan fiskus terhadap kepatuhan wajib pajak, pengaruh kesadaran perpajakan terhadap kepatuhan wajib pajak. Masing-masing hipotesis penelitian tersebut akan dijelaskan pada bagian di bawah ini :

Tabel 3. Uji Statistik

\begin{tabular}{|c|c|c|c|c|c|c|c|}
\hline \multirow{2}{*}{\multicolumn{2}{|c|}{ Model }} & \multicolumn{2}{|c|}{ Unstandardized Coefficients } & \multirow{2}{*}{\multicolumn{2}{|c|}{$\frac{\text { Standardized Coefficients }}{\text { Beta }}$}} & \multirow[b]{2}{*}{$t$} & \multirow[b]{2}{*}{ Sig. } \\
\hline & & $\mathrm{B}$ & Std. Error & & & & \\
\hline 1 & (Constant) & .733 & .443 & & & 1.655 & .102 \\
\hline & $\mathrm{X} 1$ & .191 & .094 & & .214 & 2.039 & .045 \\
\hline & $\mathrm{X} 2$ & .207 & .118 & & .193 & 1.758 & .083 \\
\hline & X3 & .361 & .110 & & .341 & 3.275 & .002 \\
\hline
\end{tabular}

a. Dependent Variable: Y

Sumber data diolah (2016)

\subsection{Pembahasan}

1. Pembahasan Hipotesis Sikap Wajib Pajak Pada Pelaksanaan Sanksi Denda Terhadap Kepatuhan Wajib Pajak

Tingkat signifikasi variabel bebas sikap WP pada pelaksanaan sanksi denda adalah sebesar 0,045 yang lebih kecil apabila dibandingkan dengan tingkat signifikansi statistik sebesar 0,05. Berdasarkan hal tersebut maka variabel sikap wajib pajak pada pelaksanaan sanksi denda berpengaruh positif signifikan terhadap kepatuhan wajib pajak. 
Dalam theory of planned behavior, Control beliefs berkaitan dengan sanksi pajak yaitu dibuat untuk mendukung agar wajib pajak mematuhi peraturan perpajakan. Kepatuhan formal wajib pajak akan ditentukan berdasarkan persepsi wajib pajak tentang seberapa kuat sanksi pajak mampu mendukung perilaku wajib pajak untuk taat pajak. Fraternesi (2001) menyatakan bahwa WP akan mematuhi pembayaran pajak bila memandang sanksi denda akan lebih banyak merugikannya. Semakin banyak sisa tunggakan pajak yang harus dibayar WP, maka akan semakin berat bagi WP untuk melunasinya.

Pertanyaan pertama dalam variabel Sanksi ini adalah "Anda merasa bahwa sudah sepantasnya keterlambatan membayar pajak tidak diampuni dan harus dikenakan bunga". Ratarata jawaban responden atas pertanyaan ini adalah sebesar 3,3 yang artinya bahwa secara umum responden menjawab tidak pasti untuk pertanyaan ini. Nilai minimal untuk jawaban responden atas pertanyaan ini adalah 2 yang artinya terdapat responden yang menjawab tidak setuju, sementara itu nilai maksimal jawaban responden atas pertanyaan ini adalah 5 yang artinya terdapat responden yang menjawab sangat setuju. Pertanyaan kedua adalah "Denda sebesar 2\% per bulan adalah wajar". Nilai rata-rata jawaban responden atas pertanyaan ini adalah 3.41 yang artinya secara umum responden menjawab tidak pasti. Nilai minimal untuk jawaban responden atas pertanyaan ini adalah 2 yang artinya terdapat responden yang menjawab tidak setuju, sementara itu nilai maksimal jawaban responden atas pertanyaan ini adalah 5 yang artinya terdapat responden yang menjawab sangat setuju.

Pertanyaan ketiga adalah "Pelaksanaan sanksi denda terhadap WP yang lalai oleh petugas pajak tepat pada waktunya". Nilai rata-rata jawaban responden atas pertanyaan ini adalah 3,74 yang artinya secara umum responden menjawab setuju. Nilai minimal untuk jawaban responden atas pertanyaan ini adalah 2 yang artinya terdapat responden yang menjawab tidak setuju, sementara itu nilai maksimal jawaban responden atas pertanyaan ini adalah 5 yang artinya terdapat responden yang menjawab sangat setuju.

Pertanyaan keempat adalah "Perhitungan pelaksanaan sanksi denda bunga terhadap WP yang lalai membayar pajak dilakukan oleh WP yang bersangkutan". Nilai rata-rata jawaban responden atas pertanyaan ini adalah 4,05 yang artinya secara umum responden menjawab setuju. Nilai minimal untuk jawaban responden atas pertanyaan ini adalah 2 yang artinya terdapat responden yang menjawab tidak setuju, sementara itu nilai maksimal jawaban responden atas pertanyaan ini adalah 5 yang artinya terdapat responden yang menjawab sangat setuju. Dari data yang diperoleh dari pertanyaan-pertanyaan dalam variabel sikap wajib pajak pada sanksi denda, kebanyakan responden menjawab tidak pasti. Sikap wajib pajak pada sanksi denda dapat lebih ditingkatkan dengan cara memberikan sosialisasi, penyuluhan secara gratis kepada wajib pajak yang baru atau secara berkala mengirimkan pemberitahuan pengenai pelaksanaan sanksi denda agar kepatuhan wajib pajak dapat lebih tinggi.

\section{Pembahasan Hipotesis Pelayanan Fiskus Terhadap Kepatuhan Wajib Pajak}

Tingkat signifikasi variabel bebas Pelayanan Fiskus adalah sebesar 0,085 yang lebih besar apabila dibandingkan dengan tingkat signifikansi statistik sebesar 0,05 . Berdasarkan hal tersebut maka variabel pelayanan fiskus tidak berpengaruh signifikan terhadap kepatuhan wajib pajak.

Dalam theory of planned behavior, Normative beliefs berkaitan dengan pelayanan fiskus, yaitu ketika akan melakukan sesuatu, individu akan memiliki keyakinan tentang harapan normatif dari orang lain dan motivasi untuk memenuhi harapan tersebut dan dengan adanya pelayanan yang baik dari petugas pajak, sistem perpajakan yang efisien dan efektif, serta penyuluhan-penyuluhan pajak yang memberikan motivasi kepada wajib pajak agar taat pajak, akan membuat wajib pajak memiliki keyakinan atau memilih perilaku taat pajak 
Temuan ini konsisten dengan hasil penelitian Iva Farida Hidayati (2014) yang juga menemukan bahwa pelayanan fiskus tidak berpengaruh terhadap kepatuhan wajib pajak di KPP Pratama Surakarta, penelitian ini dilakukan kepada wajib pajak orang pribadi yang terdaftar di Kantor Pelayanan Pajak Pratama Surakarta yang tergolong sebagai wajib pajak efektif, Iva farida Hidayati mengatakan bahwa semakin wajib pajak mendapatkan pelayanan yang terbaik, maka kepatuhan wajib pajak dalam membayar pajak akan berkurang. Hal ini sama dengan hasil penelitian yang dilakukan pada wajib pajak orang pribadi di Kota Manado dan di Kabupaten Minahasa, dimana penulis mendapati bahwa semakin baik pelayanan yang dilakukan oleh fiskus kepada wajib pajak, maka kepatuhan wajib pajak tidak akan bertambah. Hal ini disebabkan sistem menghitung pajak sendiri (self assesment system) membuat pembayaran pajak berada dipihak wajib pajak itu sendiri.

Pertanyaan pertama dalam variabel pelayanan fiskus ini adalah "Fiskus telah memberikan pelayanan pajak dengan baik". Nilai rata-rata jawaban responden atas pertanyaan ini adalah 3.47 yang artinya secara umum responden menjawab setuju. Nilai minimal untuk jawaban responden atas pertanyaan ini adalah 2 yang artinya terdapat responden yang menjawab tidak setuju, sementara itu nilai maksimal jawaban responden atas pertanyaan ini adalah 5 yang artinya terdapat responden yang menjawab sangat setuju.

Pertanyaan kedua adalah "Dalam menentukan pajak, ketetapan tarifnya telah adil". Nilai rata-rata jawaban responden atas pertanyaan ini adalah 3.6 yang artinya secara umum responden menjawab setuju. Nilai minimal untuk jawaban responden atas pertanyaan ini adalah 2 yang artinya terdapat responden yang menjawab tidak setuju, sementara itu nilai maksimal jawaban responden atas pertanyaan ini adalah 5 yang artinya terdapat responden yang menjawab sangat setuju atas pernyataan ini.

Pertanyaan ketiga adalah "Anda merasa bahwa penyuluhan yang dilakukan oleh Fiskus dapat membantu pemahaman anda mengenai hak dan kewajiban anda selaku WP". Nilai rata-rata jawaban responden atas pertanyaan ini adalah 3,64 yang artinya secara umum responden menjawab setuju. Nilai minimal untuk jawaban responden atas pertanyaan ini adalah 2 yang artinya terdapat responden yang menjawab tidak setuju, sementara itu nilai maksimal jawaban responden atas pertanyaan ini adalah 5 yang artinya terdapat responden yang menjawab sangat setuju atas pernyataan ini

Pertanyaan keempat adalah "Cara membayar dan melunasi pajak adalah mudah / efisien". Nilai rata-rata jawaban responden atas pertanyaan ini adalah 3.3 yang artinya secara umum responden menjawab tidak pasti. Nilai minimal untuk jawaban responden atas pertanyaan ini adalah 2 yang artinya terdapat responden yang menjawab tidak setuju, sementara itu nilai maksimal jawaban responden atas pertanyaan ini adalah 5 yang artinya terdapat responden yang menjawab sangat setuju atas pernyataan ini.

Dari data yang diperoleh dari pertanyaan-pertanyaan dalam variabel pelayanan fiskus, kebanyakan responden menjawab setuju. Untuk itu fiskus dapat bertindak sesuai dengan standar operasional prosedur sesuai yang ditetapkan, tanpa perlu melakukan inovasi-inovasi yang baru untuk meningkatkan kepatuhan wajib pajak.

\section{Pembahasan Hipotesis Kesadaran Perpajakan Terhadap Kepatuhan Wajib Pajak}

Tingkat signifikasi variabel bebas kesadaran perpajakan adalah sebesar 0,002 yang lebih kecil apabila dibandingkan dengan tingkat signifikansi statistik sebesar 0,05. Berdasarkan hal tersebut maka variabel kesadaran perpajakan berpengaruh positif signifikan terhadap kepatuhan wajib pajak. 
Dalam theory of planned behavior, Behavioral beliefs berkaitan dengan kesadaran wajib pajak, yaitu ketika sebelum individu melakukan sesuatu, individu tersebut akan memiliki keyakinan mengenai hasil yang akan diperoleh dari perilakunya, sehingga individu tersebut memutuskan bahwa akan melakukannya atau tidak melakukannya.

Penelitian Suyatmin (2004) menunjukkan bahwa sikap wajib pajak terhadap kesadaran perpajakan berpengaruh positif terhadap kepatuhan wajib pajak. Soemarso (1998) menyatakan bahwa kesadaran perpajakan masyarakat yang rendah seringkali menjadi salah satu sebab banyaknya potensi pajak yang tidak dapat dijaring. Lerche (1980) juga mengemukakan bahwa kesadaran perpajakan seringkali menjadi kendala dalam masalah pengumpulan pajak dari masyarakat. Kesadaran wajib pajak atas perpajakan amatlah diperlukan guna meningkatkan kepatuhan wajib pajak untuk itu dinas pendapatan Kota Manado dan dinas pendapatan kabupaten Minahasa perlu membuat sosialisasi untuk meningkatkan kesadaran perpajakan bagi wajib pajak yang ada.

Ada empat indikator yang digunakan untuk variabel Sadar. Pertanyaan pertama adalah “ Pajak adalah iuran rakyat untuk dana pembangunan. Nilai rata- rata jawaban responden atas pertanyaan ini adalah 3.43 yang artinya secara umum responden menjawab tidak pasti. Nilai minimal untuk jawaban responden atas pertanyaan ini adalah 2 yang artinya terdapat responden yang menjawab tidak setuju, sementara itu nilai maksimal jawaban responden atas pertanyaan ini adalah 5 yang artinya terdapat responden yang menjawab sangat setuju atas pernyataan ini.

Pertanyaan kedua adalah "Pajak adalah iuran rakyat untuk dana pengeluaran umum pelaksanaan fungsi dan tugas pemerintah". Nilai rata-rata jawaban responden atas pertanyaan ini adalah 3.38 yang artinya secara umum responden menjawab tidak pasti. Nilai minimal untuk jawaban responden atas pertanyaan ini adalah 2 yang artinya terdapat responden yang menjawab tidak setuju, sementara itu nilai maksimal jawaban responden atas pertanyaan ini adalah 5 yang artinya terdapat responden yang menjawab sangat setuju atas pernyataan ini.

Pertanyaan ketiga adalah "Pajak merupakan salah satu sumber dana pembiayaan pelaksanaan fungsi dan tugas pemerintah". Nilai rata-rata jawaban responden atas pertanyaan ini adalah 3.4 yang artinya secara umum responden menjawab tidak pasti. Nilai minimal untuk jawaban responden atas pertanyaan ini adalah 2 yang artinya terdapat responden yang menjawab tidak setuju, sementara itu nilai maksimal jawaban responden atas pertanyaan ini adalah 5 yang artinya terdapat responden yang menjawab sangat setuju atas pernyataan ini.

Pertanyaan keempat adalah "Anda merasa yakin bahwa pajak yang sudah anda bayar benar-benar digunakan untuk pembangunan". Nilai rata-rata jawaban responden atas pertanyaan ini adalah 3.6 yang artinya secara umum responden menjawab setuju. Nilai minimal untuk jawaban responden atas pertanyaan ini adalah 2 yang artinya terdapat responden yang menjawab tidak setuju, sementara itu nilai maksimal jawaban responden atas pertanyaan ini adalah 5 yang artinya terdapat responden yang menjawab sangat setuju atas pernyataan ini.

Dari data yang diperoleh dari pertanyaan-pertanyaan dalam variabel kesadaran perpajakan, dapat diketahui bahwa kebanyakan responden penelitian ini masih memiliki kesadaran perpajakan yang tidak pasti. Kesadaran perpajakan dapat lebih ditingkatkan dengan cara memberikan sosialisasi melalui iklan di televisi, radio maupun surat kabar serta media lainnya agar kepatuhan wajib pajak dapat lebih tinggi. 


\section{KESIMPULAN DAN SARAN \\ Kesimpulan}

1. Sikap wajib pajak pada pelaksanaan sanksi denda secara parsial memiliki pengaruh positif terhadap kepatuhan WP. Hal ini menunjukkan bahwa makin tinggi sikap WP pada pelaksanaan sanksi denda maka makin tinggi pula kepatuhan wajib pajak.

2. Pelayanan fiskus secara parsial tidak memiliki pengaruh terhadap kepatuhan WP. Hal ini menunjukkan bahwa pelayanan fiskus kepada wajib pajak tidak membuat kepatuhan wajib pajak meningkat.

3. Kesadaran perpajakan secara parsial memiliki pengaruh positif terhadap kepatuhan WP. Hal ini menunjukkan bahwa makin tinggi Kesadaran perpajakan maka makin tinggi pula kepatuhan wajib pajak.

\section{Saran}

1. Sanksi denda harus disosialisasikan dengan baik kepada para WP agar WP dapat memahami hal-hal yang berkaitan dengan pelaksanaan sanksi denda serta penyebab-penyebab dikenakannya suatu sanksi denda terhadap WP. Sosialisasi ini dapat dilakukan dengan memberikan penyuluhan secara gratis bagi para WP baru atau secara berkala mengirimkan pemberitahuan mengenai pelaksanaan sanksi denda.

2. Sistem menghitung pajak sendiri (self assesment system) membuat pelayanan fiskus menjadi tidak penting bagi peningkatan kepatuhan wajib pajak. Dalam hal pelayanan kepada wajib pajak, fiskus bertindak sesuai dengan standar operasional prosedur sesuai yang ditetapkan, tanpa perlu melakukan inovasi-inovasi yang baru.

3. Perlu disosialisasikan sikap sadar membayar pajak di masyarakat. Sosialisasi ini dapat melalui iklan di televisi, radio maupun surat kabar serta media lainnya. Bila perlu secara berkala Dinas Pendapatan di Kota Manado dan di Kabupaten Minahasa mengadakan acara yang mendidik serta menghibur masyarakat agar memiliki kesadaran perpajakan.

\section{DAFTAR PUSTAKA}

Ajzen, Icek (1991), The Theory of Planned Behavior, Organization and Human Decision Processes 50, 179-211 (1991), Academic Press.Inc.

Boediono, (2003), Pelayanan Prima Perpajakan., Jakarta : Rineka Cipta..

Cohen-Charash, Y., dan Spector, P. E. 2001. The role of justice in organizations: A metaanalysis. Organizational Behavior and Human Decision Processes, 86 (2): 278-321

Deden Saefudin (2003), "Hukuman dan Penghargaan Untuk Wajib Pajak," Berita Pajak, No. 1492/Tahun XXXV.

Devano, S. dan Rahayu, S. K. 2006. Perpajakan Konsep, Teori dan Isu. Jakarta: Prenada Media

Ghozali, Imam. 2013. Aplikasi Analisis Multivariat Dengan Program SPSS, Cetakan Ketujuh . Badan Penerbit Universitas Diponegoro. Semarang

Ilyas, W. B. dan Burton, R. 2008. Hukum Pajak (Edisi 4). Jakarta: Salemba Empat.

Jogiyanto, H.M. 2007. Sistem Informasi Keperilakuan. Yogyakarta: Penerbit Andi.

Lerche, Dietrich (1980), "Efficiency of Taxation in Indonesia," BIES, Vol. 16 No. 1.

Malle, Bertram F. (2011), Attribution Theories: How People Make Sense of Behavior, dalam Chadee D. (ed.), Theories in Social Psychology (pp.72-95), Wiley-Blackwell.

Miando Sahala H. Panggabean (2002), "Self Assessment, Fiskus dan Kepatuhan Wajib Pajak," Berita Pajak, No. 1462/Tahun XXXIV.

M. Said (2003), "Fenomena Pajak," Berita Pajak, No. 1488/Tahun XXXV.

Mardiasmo. 2013. Perpajakan (Edisi Revisi 2011). Yogyakarta: Penerbit Andi. 
Novak, Norma D. (1989), Tax Administration in Theory and Practice, London : Preager Publisher.

Novitasari, Fin., (2007)., Analisis Faktor - Faktor Yang Mempengaruhi Kepatuhan Wajib Pajak Dalam Memenuhi Kewajiban Pajak., Skripsi Universitas Kristen Petra Surabaya.

Nurmanto., Safri., (2003)., Pengantar Perpajakan., (edisi kedua)., Jakarta : Granit.

Peraturan Daerah Nomor 2 tahun 2011 tentang Pajak Daerah

Peraturan Daerah Nomor 1 tahun 2011 tentang Pajak Daerah Kabupaten Minahasa

Priantara, Diaz. 2012. Perpajakan Indonesia (Edisi 2). Jakarta: Mitra Wacana Media.

Robbins, Judge. 2008. Perilaku Organisasi, Edisi Duabelas, Penerbit Salemba Empat: Jakarta.

Robbins, Stephen P. (1996) Perilaku Organisasi : Konsep, Kontroversi dan Aplikasi, Edisi Bahasa Indonesia, Prenhallindo, Jakarta.

Rustiyaningsih, Sri., (2011)., Faktor - Faktor Yang Mempengaruhi Kepatuhan Wajib Pajak., Widya Warta No.02 Tahun XXXV / Juli 2011.

Santi, A. N. 2012. Analisis Pengaruh kesadaran Perpajakan, Sikap Rasional, Lingkungan, Sanksi Denda, dan Sikap Fiskus Terhadap kepatuhan Wajib Pajak, E-Journal Universitas Diponegoro Semarang, (Online), (http://eprints.undip.ac.id/, diakses 17 November 2013).

Siat, Cahyaputra Christian., dan Toly, Agus Arianto., (2013)., Faktor - Faktor Yang Mempengaruhi Kepatuhan Wajib Pajak Dalam Memenuhi Kewajiban Membayar Pajak di Surabaya., Tax\&Accounting Review, Vol.1, No.1, 2013.

Soemarso S.R. (1998), "Dampak Reformasi Perpajakan 1984 Terhadap Efisiensi Sistem Perpajakan Indonesia," Ekonomi dan Keuangan Perpajakan di Indonesia, Vol. 46 No. 3.

Suandy, E. 2008. Hukum Pajak (Edisi 4). Jakarta: Salemba Empat. 